\title{
Recent advances on bio-alcohol production from syngas using microorganisms
}

\author{
Ji Eun Woo ${ }^{1} \cdot$ Yu-Sin Jang ${ }^{1}$ \\ 미생물을 이용한 합성가스로부터 바이오 알코올 생산 최신 동향
}

우지은 ${ }^{1}$ - 장유신1

Received: 15 August 2017 / Accepted: 15 September 2017 / Published Online: 31 December 2017

(C) The Korean Society for Applied Biological Chemistry 2017

\begin{abstract}
Cellulosic alcohol fermentation has recently gained more attention in the production of ethanol, butanol, and 2,3butanediol. However, it was revealed that the process had several hurdles, such as, an expensive cost for biomass decomposition to yield fermentable sugars and a production of byproduct lignin. As an alternative for the process through biomass saccharification, the alcohol production through syngas from biomass has been studied. In this study, we reviewed acetogen and its central metabolic pathway, Wood-Ljungdahl route, capable of utilizing syngas. Furthermore, the metabolic engineering strategies of acetogen for bio-alcohol production from syngas was also reviewed with a brief perspective.
\end{abstract}

Keywords Acetogen ' Butanol · Ethanol - Syngas · WoodLjungdahl pathway

Yu-Sin Jang $(\bowtie)$

E-mail: jangys@gnu.ac.kr

${ }^{1}$ Institute of Agriculture \& Life Science (IALS), Department of Agricultural Chemistry and Food Science Technology, Division of Applied Life Science Technology (BK21 Plus), Gyeongsang National University, Jinju 52828, Republic of Korea

This is an Open Access article distributed under the terms of the Creative Commons Attribution Non-Commercial License (http://creativecommons. org/licenses/by-nc/3.0/) which permits unrestricted non-commercial use, distribution, and reproduction in any medium, provided the original work is properly cited.
서 론

인류가 환경에 미치는 부작용을 크게 인지하지 못하고 누렸던 혜택 중 하나가 석유자원을 과다하게 이용하는 것이었다. 비교 적 최근에서야 이러한 석유자원의 무분별한 사용으로 지구 온 난화와 같은 심각한 기후변화 문제가 야기되고 있음을 인지하 게 되었다. 기후변화에 대응하기 위한 목적으로 바이오에너지 및 바이오화합물 생산을 위한 바이오리파이너리 기술들이 하나 의 대안으로써 주목 받고 있다(Anbarasan 등, 2012; Jang 등, 2012c; Clomburg 등, 2017). 바이오리파이너리는 바이오매스로 부터 미생물 등의 촉매를 이용하여 바이오연료와 바이오화합물 등을 생산하는 기술로 알려져 있다(Zverlov 등, 2006; Tracy 등, 2012). 즉, 석유자원을 시추하여 정제 및 촉매반응을 통하여 생 산하던 다양한 용도의 화합물들을 바이오매스로부터 생산하고 자 하는 개념이다. 특히, 바이오 알코올인 에탄올 및 부탄올의 경우는 바이오 연료로써, 그리고 2,3-부탄디올을 포함한 앞서 언 급한 바이오 알코올 모두는 기초 유분 대체제로도 큰 관심을 끌고 있다(Straathof 2014).

바이오 알코올 생산을 위한 바이오매스로 활용하기 가장 쉬 운 재료는 전분과 설탕이다. 그 이유는 바이오 알코올을 생산 하는 미생물들이 가장 잘 이용할 수 있는 포도당 또는 자당 (sucrose)을 쉽게 확보할 수 있기 때문이다. 전분은 옥수수, 감 자 등 다양한 작물로 부터 쉽게 확보할 수 있으며, 설탕은 사 탕수수 등으로부터 용이하게 획득할 수 있다. 이러한 이유로, 한 때 이들 식용 바이오매스를 이용한 바이오 알코올 생산이 큰 관심의 대상이 되기도 하였다. 실제 미국의 바이오 에탄올 생산의 대부분은 아직도 옥수수 전분으로부터 만들어지고 있고, 브라질의 경우는 사탕수수부터 수득한 설탕을 이용하여 생산되 고 있다(Jang 등, 2012a). 하지만, 옥수수 전분 및 설탕과 같은 식량자원인 식용바이오매스를 바이오 연료용 알코올 생산에 이 용하는 것에 대한 사회적 반감이 높아져 대체 바이오매스의 개 
발이 필요하게 되었다. 대안으로 고려되고 있는 것이 폐목재, 농 업부산물 등과 같은 목질계 바이오매스이며, 좀 더 먼 미래의 바이오매스로써 조류가 고려되고 있다(Lynd 등, 2005; Ragauskas 등, 2006; Sauer 등, 2008; Becker and Wittmann 2012; Chen and Patel 2012).

농업 및 산림업에서 다량 수득할 수 있는 목질계 바이오매스 는 가장 현실적인 바이오매스로 고려되고 있다(Kim 등, 2015). 이들 목질계 바이오매스는 셀룰로스, 헤미셀룰로스, 리그닌으로 구성되어 있다(Lee 등, 2016). 하지만, 목질계 바이오매스로부터 바이오화합물을 생산하는 미생물이 이용하기 위한 당을 확보하 고, 이를 미생물이 이용하는 과정에서 많은 비용과 문제가 발 생한다(Kim 등, 2016a). 최근, 목질계 바이오매스의 전처리를 위한 많은 기술들이 개발되었다 할지라도 여전히 풀지 못한 문 제들이 남아있다(Kim 등, 2016b). 대표적인 예로써 목질계 바 이오매스 중 약 $30 \%$ 를 차지하는 리그닌은 부산물로 발생하게 된다(Cho 등, 2009). 즉, 전체 목질계 바이오매스의 $30 \%$ 는 아 직도 활용이 불가하다는 것이다.

목질계 바이오매스 전체를 활용하기 위한 방법으로써, 바이 오매스를 부분산화시켜 가스화한 합성가스(synthetic gas, syngas) 를 이용하는 방법이 큰 관심을 받고 있다(Lagoa-Costa 등, 2017). 목질계 바이오매스로부터 확보 가능한 합성가스는 일산 화탄소와 수소로 구성되어 있으며, 합성가스를 탄소원으로 이용 가능한 미생물을 이용하여 바이오 알코올을 생산한다면 리그닌 까지 거의 완벽하게 이용할 수 있다(Lagoa-Costa 등, 2017). 합 성가스로부터 바이오 알코올을 생산하기 위해서는 일산화탄소 를 탄소원으로써 이용 가능한 대사회로를 가진 미생물이 필요 하다. 본 고에서는 일산화탄소 및 이산화탄소를 탄소원으로, 수 소를 환원력 공급원으로 이용 가능한 아세토젠(acetogen) 미생 물들과 우드-륭달 대사회로를 소개하고, 이 대사회로를 통하여 바이오 알코올을 생산하기 위하여 사용된 최신 균주 개발 전략 을 리뷰하고자 한다.

\section{아세토젠(acetogen)}

아세토젠은 아세트산을 생산한다는 점에서 Acetobacter aceti 등 과 같은 초산균과 유사한 특징을 보이지만, 아세트산을 생합성 하는 경로에 의하여 구분 가능하다. 초산균은 에탄올을 산화시 켜 아세트산을 생합성 하는 대사회로를 가지고 있는 반면, 아 세토젠은 이산화탄소 또는 일산화탄소의 환원반응을 통하여 acetyl-CoA를 생합성한 후 아세트산으로 전환시키는 경로를 가 진 절대혐기성 미생물이다. 대표적으로 알려진 아세토젠으로 Clotridium aceticum, Moorella thermoacetica, Clostridium autoethanogenum, Clostridium ljungdahlii 등이 있으며, 이들 중 일 부는 최근 바이오화합물 생산을 위한 숙주로써 큰 주목을 받고 있다(Durre and Eikmanns 2015). 최초로 분리된 아세토젠은 $C$. aceticum 이며, 그람음성의 간균으로 알려져 있다(Durre and Eikmanns 2015). C. aceticum은 수소-환원력 기반 이산화탄소 조건 및 일산화탄소 조건에서 이들을 탄소원으로 이용하여 성 장이 가능한 미생물로 알려져 있다(Tracy 등, 2012). C. autoethanogenum과 C. ljungdahlii 역시 이산화탄소 및 일산화탄소 를 탄소원으로 이용할 수 있는 균주들이며, 이들은 아세트산 외 에도 에탄올을 자연적으로 생산하는 것으로 알려져 있다(Jones 등, 2016). 즉, 이들 아세토젠은 이산화탄소 및 일산화탄소로부
터 최종 아세트산 및 에탄올을 생산할 수 있으며, 이들 화합물 들은 acetyl-CoA 생합성 경로를 거쳐서 만들어진다. 따라서, acetyl-CoA를 전구체로하여 생합성 가능한 바이오화합물의 생산 에 숙주로써 유용하게 활용할 수 있을 것으로 기대를 모으고 있다. 하지만, 바이오 알코올 생산을 위한 균주로 개발함에 있 어서는 수율 향상을 위하여 부산물인 아세트산 생합성 경로의 조절이 필요할 것으로 판단된다.

\section{우드-륭달 대사회로(Wood-Ljungdahl pathway)}

우드-륭달 대사회로는 크게 두개의 나누어진 갈래가 합쳐져서 최종 acetyl-CoA를 생합성 하는 형태를 취한다(Fig. 1). 나눠진 두 갈래는 회로 최종산물인 acetyl-CoA의 acetyl 그룹을 구성하 기 위한 메틸 $\left(\mathrm{CH}_{3}-\right)$ 그룹과 카보닐 $(\mathrm{CO})$ 그룹을 각각 제공하는 역할을 하는 것으로 알려져 있다(Jones 등, 2016). 이산화탄소 로부터 메틸그룹이 만들어지는 갈래에서는 tetrahydrofolate (THF)가 관여하게 되며, formate dehydrogenase에 의해 이산화 탄소가 개미산으로 전환된 다음 $\mathrm{THF}$ 와 반응하여 formyl-THF 로 전환된다(Fig. 1). 다시 methenyl-THF 및 methylene-THF를 거쳐, methyl-THF로 환원된다(Fig. 1). 메틸그룹을 제공하기 위 한 갈래에서, 이산화탄소가 메틸이 되기까지는 총 3 몰의 환원 력이 필요하게 된다. Methyl-THF의 메틸그룹은 methyltransferase 에 의해 iron-sulfur corrinoid 단백질로 전달되어 최종 acetyl$\mathrm{CoA}$ 생합성 반응에 제공된다. 한편, 카보닐 그룹을 제공하는 갈래에서는 carbon monoxide dehydrogenase (CODH) 효소에 의해 이산화탄소에서 카보닐 그룹으로 환원되고, 최종 acetyl$\mathrm{CoA}$ synthase/CODH 효소 복합체의 작용을 통한 acetyl-CoA 생합성 반응에 제공된다. 따라서, 카보닐 그룹을 제공하기 위한 갈래에서는 1 몰의 환원력을 요구하게 된다. 즉, 우드-륭달 대 사회로는 환원력의 생산은 전혀 없이, 1 몰 acetyl-CoA 생합성 마다 4 몰의 환원력을 제공해야 한다. 아세토젠에서 이러한 환 원력의 공급은 세포막에서 일어나는 산화/환원 반응을 통하여 제공되며, 아세토젠에 풍부한 ferredoxins, rubredoxins, quinones, cytochromes 등과 같은 전자 캐리어들이 우드-륭달 대사회로의 산화/환원 반응에 관여하는 것으로 알려져 있다(Islam 등, 2015).

우드-륭달 대사회로의 ATP 밸런스를 살펴보면, 메틸 그룹을 제공하기 위한 갈래에서 개미산과 THF가 반응하여 formyl-THF 가 생합성 되는 과정에서 1 몰의 $\mathrm{ATP}$ 가 소비된다. 이 $\mathrm{ATP}$ 의 소비는 acetyl-CoA가 acetyl-phosphate로 전환된 후, 아세트산으 로 전환되는 과정에서 생산되는 1 몰의 $\mathrm{ATP}$ 로 보상될 수 있다 (Kopke 등, 2010).

환원력 공급을 고려하지 않고, 단순 carbon recovery 측면에 서만 볼 때, 전분질계 또는 목질계 바이오매스로부터 수득한 포 도당을 이용하여 바이오화합물 생산을 위한 주요 전구체인 acetyl-CoA를 생합성한다면, 탄소 6 개로 구성된 포도당 1 몰로 부터 2 몰 acetyl-CoA를 수득할 수 있다. 반면, 동일한 6개의 탄소 (6 몰 이산화탄소)로부터 우드-륭달 대사회로를 통하여 생 합성 가능한 acetyl-CoA는 3 몰이 될 수 있다. 이와 같은 $100 \%$ carbon recovery가 가능한 특징은 포도당을 이용한 대사회로 보 다 바이오화합물 생산을 위한 대사회로로써 가능성을 보여 준 다. 하지만, 실제 수율은 환원력 공급에 크게 영향을 받기 때문 에 매우 낮아질 것으로 예상되며, 이를 조절하기 위한 대사공 학 전략의 개발이 요구된다. 


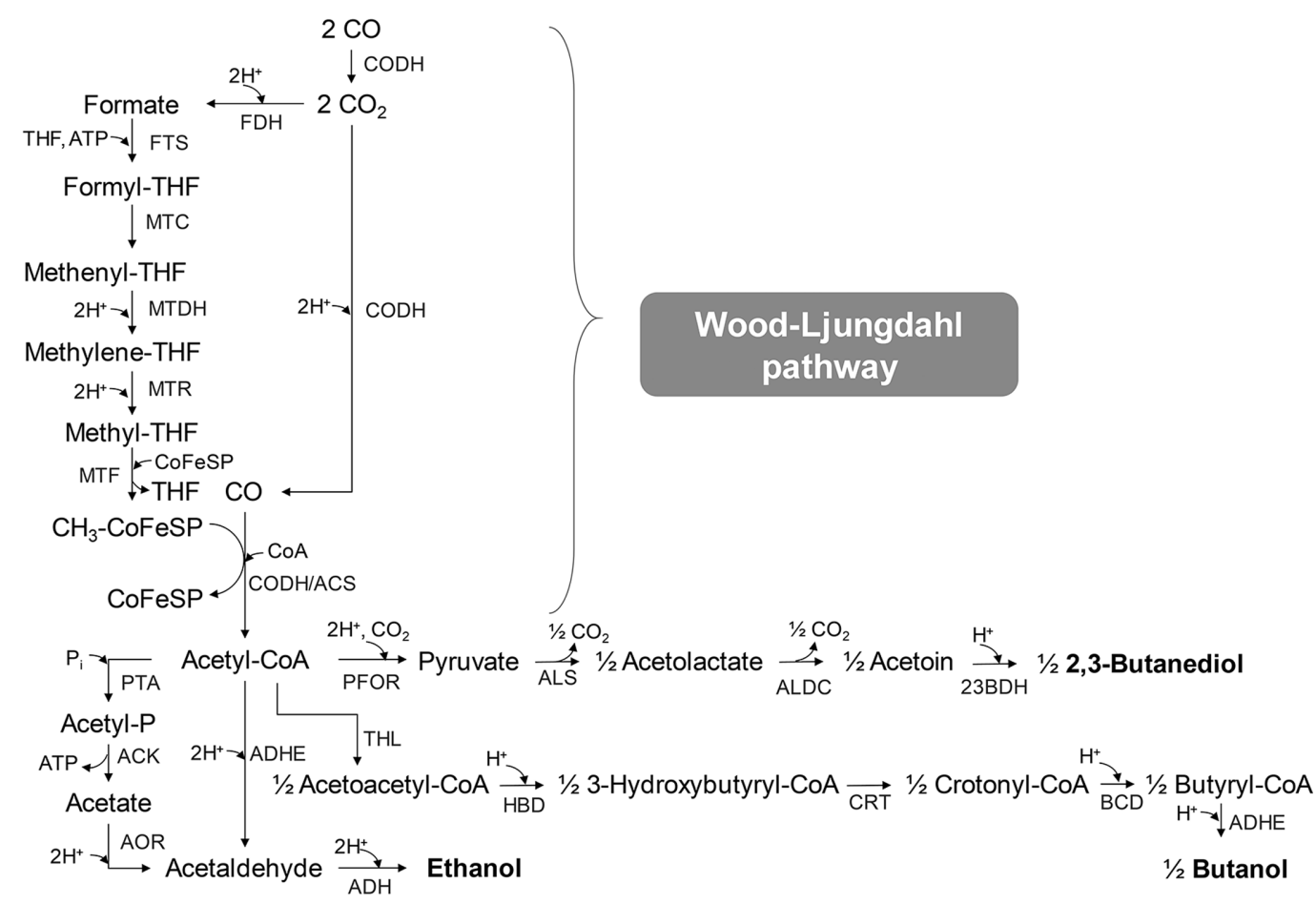

Fig. 1 Schematic metabolic pathway of acetogen for the production of ethanol, butanol, and 2,3-butanediol from syngas. The abbreviations of enzymes are; CODH/ACS, carbon monoxide dehydrogenase (CODH)/acetyl-CoA synthase (ACS) complex; FDH, formate dehydrogenase; FTS, formyl tetrahydrofolate synthase; MTC, methenyl tetrahydrofolate cyclohydrolase; MTDH, methylene tetrahydrofolate dehydrogenase; MTR, methylene tetrahydrofolate reductase; MTF, methyltransferase; PFOR, pyruvate/ferredoxin oxidoreductase; ALS, acetolactate synthase; ALDC, acetolactate decarboxylase; 23BDH, 2,3-butanediol dehydrogenase; PTA, phosphotransacetylase; ACK, acetate kinase; AOR, aldehyde ferredoxin oxidoreductase; ADHE, aldehyde/alcohol dehydrogenase; ADH, alcohol dehydrogenase; THL, thiolase; HBD, 3-hydroxybutyryl-CoA dehydrogenase; CRT, crotonase; and $\mathrm{BCD}$, butyryl-CoA dehydrogenase

\section{합성가스로부터 바이오 알코올 생산 균주 개발 전략}

앞서 언급한 것과 같이, 최근 바이오화합물 생산에 우드-륭달 대사회로 및 아세토젠을 이용하기 위한 노력과 연구들이 활발 히 진행되고 있다. 본 섹션에서는 우드-륭달 대사회로를 통하여 이산화탄소 또는 일산화탄소를 에탄올, 부탄올, 2,3-부탄디올로 전환하기 위한 미생물 개발 대사공학 전략들을 정리하였다.

\section{에탄올}

에탄올은 미국과 브라질에서 바이오연료로 사용되고 있으며, 국 내에서는 고급휘발유의 옥탄가를 맞추기 위한 용도로 일부 사 용하고 있다(Jang 등, 2012a). 뿐만 아니라, 코카콜라 등에서 사 용하고 있는 plant bottle의 제조에도 일부 사용되고 있어 향후 바이오화합물로써 사용처가 확대될 것으로 전망되고 있다. 전분 이나 사탕수수로부터 유래한 당을 이용한 Saccharomyces cerevisiae 에탄올 발효기술은 100년 이상된 공정이 잘 개발되 어 있다. 최근, 이들 식용바이오매스 대신 목질계 바이오매스 이용 시에는 5 탄당을 이용하지 못하는 문제가 있어 이를 해결 하기 위한 노력들이 활발히 진행되고 있다(Chu and Lee 2007). 이러한 문제들과 리그닌으로 인한 낮은 바이오매스 이용 효율 을 극복하기 위한 노력으로 합성가스로부터 에탄올 생산 또한 높은 관심을 끌고 있다.

자연적으로 에탄올을 생산 가능한 아세토젠은 C. ljungdahlii, Clostridium carboxidivorans, C. autoethanogenum 등을 포함하
여 무수히 많은 것으로 알려져 있다(Durre and Eikmanns 2015). 그 이유는 앞서 설명한 것과 같이 우드-륭달 대사회로를 통하 여 에탄올의 전구체인 acetyl-CoA가 생합성 되기 때문이다. 하 지만, acetyl-CoA는 아세트산 생합성을 위한 전구체로도 사용되 기 때문에, 에탄올 생합성에 있어서는 상호 경쟁적 관계이다. 이들 에탄올 생산 독립영양 세균들의 대부분은 다음 두 경로의 에탄올 생합성 대사회로를 가진다(Liew 등, 2017). 첫째는 acetyl-CoA로부터 acetaldehyde를 거쳐 에탄올을 생합성하는 경 로로써 aldehyde/alcohol dehydrogenase (AdhE)에 의해서 반응 이 촉매된다(Fig. 1). 나머지 경로는 아세트산이 acetaldehyde를 거쳐 에탄올로 전환되는 경로로써, 아세트산의 acetaldehyde로 전환은 aldehyde:ferredoxin oxidoreductase (AOR)이 촉매한다 (Fig. 1). 후자의 경우는 부산물로 아세트산이 생성되기도 하지 만, ATP 생산측면에서 유리한 점이 있다. 현재까지 $C$. autoethanogenum만이 에탄올 증산을 위하여 대사회로가 재설계 된 아세토젠으로 보고되어 있으며, 앞서 설명한 두가지 에탄올 생합성 경로 중 $\mathrm{AdhE}$ 가 촉매하는 대사회로를 돌연변이시키는 전략을 취하고 있다. 즉 $\mathrm{AdhE}$ 는 aldehyde dehydrogenase와 alcohol dehydrogenase 두 개의 도메인을 가진 효소로 알려져 있 다. AdhE 효소의 aldehyde dehydrogenase의 기능을 상실케하는 돌연변이를 통하여, alcohol dehydrogenase로써 기능만 할 수 있도록 하였다(Liew 등, 2017). Acetyl-CoA가 아세트산으로 먼 저 생합성 된 후 $\mathrm{AOR}$ 이 촉매하는 반응을 통하여 acetaldehyde 
Table 1 Recent advances in the production of ethanol, butanol, and 2,3-butanediol from syngas

\begin{tabular}{|c|c|c|c|c|}
\hline Product & Strain & Titer $(\mathrm{g} / \mathrm{L})$ & Description & Reference \\
\hline \multirow[t]{2}{*}{ Ethanol } & C. ljungdahlii PETC (Wild type) & 19.0 & 2-Stage fermentation & (Martin et al., 2016) \\
\hline & C. autoethanogenum (Engineered) & 2.5 & $\begin{array}{l}\text { Ald domain of the } a d h E \text { was disrupted in the engineered } \\
\text { strain. cf) } 1.4 \mathrm{~g} / \mathrm{L} \text { in a culture of the wild-type }\end{array}$ & (Liew et al., 2017) \\
\hline \multirow[t]{3}{*}{ Butanol } & C. carboxidivorans (Wild type) & 0.00026 & - & (Bruant et al., 2010) \\
\hline & C. carboxidivorans (Wild type) & 1.1 & Optimization of culture condition & (Phillips et al., 2015) \\
\hline & C. ljungdahlii (Engineered) & 0.15 & $\begin{array}{c}\text { Introduction of the } t h l A, h b d, c r t, b c d, b d h A \text {, and } \\
\text { adhE2 genes from } C \text {. acetobutylicum }\end{array}$ & (Kopke et al., 2010) \\
\hline 2,3-Butanediol & $\begin{array}{l}\text { C. ljungdahlii, C. autoethanogenum, } \\
\text { Clostridium ragsdalei, } \\
\text { Clostridium coskatii (Wild type) }\end{array}$ & $<0.36$ & - & $\begin{array}{c}\text { (Kopke et al., 2011; } \\
\text { Bengelsdorf et al., 2016) }\end{array}$ \\
\hline
\end{tabular}

로 전환 가능하며, 최종 에탄올로의 전환 반응은 돌연변이된 $\mathrm{AdhE}$ 효소가 매개하도록 대사회로를 재구성하였다. 그 결과 대 사공학을 통하여 재조합된 C. autoethanogenum은 일산화탄소로 부터 약 $2.5 \mathrm{~g} / \mathrm{L}$ 의 에탄올을 생산하였다(Liew 등, 2017). 이는 야생형 균주가 보여준 약 $1.4 \mathrm{~g} / \mathrm{L}$ 에탄올 생산보다 향상된 결과 인 것을 알 수 있다(Liew 등, 2017).

한편, 야생형 균주인 C. ljungdahlii PETC를 이용한 합성가 스 발효공정의 최적화 과정을 거쳐 에탄올 생산을 $19 \mathrm{~g} / \mathrm{L}$ 까지 향상시킨 예도 보고된 바 있다(Martin 등, 2016). 이와 같은 결 과는 연속적으로 합성가스를 공급하는 2-stage 발효를 통하여 얻은 결과이며, 1 단 발효조는 연속교반 반응기(continuouslystirred tank reactor; CSTR)로, 2단 발효조는 중공사막 모듈을 이용한 cell recycling을 통한 운전을 한 것으로 보고하고 있다 (Martin 등, 2016). 이는 합성가스로부터 에탄올을 생산함에 있 어, 기체 상태의 가스를 배양액 중에 녹여 공급하는 효율성과 고농도 생촉매의 필요성을 잘 보여주고 있다. 하지만, 경제성 향상을 위한 노력이 필요할 것으로 생각한다.

\section{부탄올}

부탄올은 에탄올이 가진 흡습성과 같은 바이오연료로써 결정적 결함이 없을 뿐만 아니라 단위 중량 당 밀도 또한 높아 가솔린 과 유사한 특성을 가지는 것으로 알려져 있다(Jang 등, 2012b). 또한, 산업용매 및 플라스틱 성형을 위한 가소제 등으로도 활 용되고 있는 주요 화합물이다. 부탄올은 Clostridium 속 미생물 대사회로를 통하여 자연적으로 생합성 가능한 것으로 알려져 있 으며, 부탄올의 증산을 위한 대사공학 연구가 활발히 진행되고 있다(Jang 등, 2012b). 최근에는 자연계에서 부탄올을 생합성 가 능한 Clostridium 속에 속하는 아세토젠을 이용한 부탄올 생합 성에도 관심이 확대되고 있다(Woo 등, 2016).

아세토젠 중에서도 부탄올 생합성을 위한 대사회로를 가지는 것으로 알려진 미생물은 많지 않다. 대표적인 부탄올 생합성 가 능한 아세토젠은 C. carboxidivorans 비교적 잘 알려져 있으며, 2010년에 이들의 게놈서열이 보고된 바 있다(Fig. 1). C. carboxidivorans의 게놈분석 결과에 따르면, 부탄올 생합성 경로 는 기존 부탄올 생합성 Clostridium 균주들과 거의 일치하는 것 으로 보고되어 있다(Bruant 등, 2010). 다만, 게놈 상에서 solventogenic 미생물들인 C. acetobutylicum과 C. beijerinckii은 $c r t-b c d-e t f B A-h b d$ 순으로 오페론을 구성하는 반면, C. carboxidivorans의 게놈에서는 crt-hbd-thl-bcd-etfBA 순으로 구성되어 있
는 차이를 보여주고 있으나, 이들 배열이 부탄올 생합성에 어 떻게 영향을 미치는 아직 알려지지 않았다. 별도 탄소원의 공 급없이, 이산화탄소, 일산화탄소, 수소를 공급한 조건에서 야생 형 C. carboxidivorans를 이용하여 약 $0.26 \mathrm{mg} / \mathrm{L}$ 의 부탄올 생산 이 보고된 바 있다(Bruant 등, 2010). 최근 동일한 야생형 $C$. carboxidivorans 배양 조건 최적화 연구에서는 부탄올 생산을 약 $1.1 \mathrm{~g} / \mathrm{L}$ 까지 달성할 수 있는 것으로 보고하고 있다(Phillips 등, 2015). 해당 연구에서는 배지에 포함되는 미량원소들의 농도를 최적화하고, 전통적으로 많이 사용되던 $\mathrm{MES}$ 완충용액을 배지 성분에서 제거하였으며, $\mathrm{N}$ 과 $\mathrm{P}$ 의 농도를 최적화 하였다(Phillips 등, 2015). 더욱 중요한 것은 탄소원으로써 사용하는 일산화탄 소가 저해 역할을 하기 때문에 이들의 농도와 배지 속으로 녹 아들어가는 정도를 조절하고 최적화 하였다. 최적 가스 공급 조 건은 $307 \mathrm{kPa}$ 에서 $\mathrm{CO}: \mathrm{H}_{2}: \mathrm{CO}_{2}$ 의 비율이 $70: 20: 10$ 이며, 이 조건 에서 앞서 언급한 $1.1 \mathrm{~g} / \mathrm{L}$ 의 부탄올 생산이 가능한 것으로 보고 하고 있다(Phillips 등, 2015).

자연적으로 부탄올을 생합성할 수 없는 C. ljungdahlii의 경 우는 외부로부터 부탄올 생합성 대사회로를 도입함으로써 합성 가스로부터 부탄올 생산 균주로 개발될 수 있었다(Kopke 등, 2010). Acetyl-CoA로부터 부탄올 생합성을 위하여 필요한 효소 들인 thiolase, 3-hydroxybutyryl-CoA dehydrogenase, crotonase, butyryl-CoA dehydrogenase, butanol/butyraldehyde dehydrogenase, butanol dehydrogenase를 각각 암호화하는 thlA, hbd, crt, bcd, $b d h A, a d h E 2$ 유전자들을 C. acetobutylicum으로부터 도입하였다. 이들 유전자의 발현은 부티르산 생합성대사회로에 관여하는 $p t b$ 프로모터를 이용하였고, 전사종결자는 아세톤 생합성 경로에 있 는 $a d c$ 유전자의 것을 사용하였다(Kopke 등, 2010). 이렇게 재 조합된 C. ljungdahlii는 합성가스로부터 약 $0.15 \mathrm{~g} / \mathrm{L}$ 정도의 부 탄올을 생합성할 수 있었으나, 발효 종료시점에서는 이들의 1/ 10 정도만이 남아 있었던 것으로 보고하고 있다(Kopke 등, 2010).

\section{2,3-부탄디올}

2,3-부탄디올은 산업적으로 많이 사용되는 메틸에틸케톤, 뷰틸로 락톤, 1,3 -부타디엔, 등 많은 화학물질 합성을 위한 전구체로 사 용되는 고부가가치 화합물로 알려져 있다(Straathof 2014). 2,3부탄디올을 생합성할 수 있는 아세토젠은 우드-륭달 대사회로 를 통하여 생합성한 acetyl-CoA를 피루브산으로 전환하여 이를 전구체로 사용하는 것으로 알려져 있다(Kopke 등, 2011). 이렇 
게 생산된 피루브산은 아세토락트산(acetolactate), 아세토인 (acetoin) 순으로 전환되고, 마지막으로 아세토인이 2,3-butanediol dehydrogenase 효소에 의해 전환됨으로써 2,3-부탄디올이 생성 된다(Fig. 1). 지금까지 알려진 2,3-부탄디올 생합성 가능한 아 세토젠은 C. ljungdahlii, C. autoethanogenum, Clostridium ragsdalei, Clostridium coskatii가 있으며, 이들 야생형 균주들 모두는 합성가스로부터 약 $0.36 \mathrm{~g} / \mathrm{L}$ 이하의 2,3-부탄디올을 생 합성하는 것으로 알려져 있다(Kopke 등, 2011; Bengelsdorf 등, 2016).

비교적 최근에 상기 아세토젠이 2,3-부탄디올을 생합성 가능 하다는 것이 밝혀졌기 때문에, 근래에 발표된 보고들은 주로 상 기 균주들의 2,3-부탄디올 생합성 대사회로에 관여하는 효소들 의 기능을 검증하고 밝히는 것에 초점이 맞춰져 있다(Kopke 등, 2014; Tan 등, 2015). 최근 한 연구에서는 C. autoethanogenum 의 피루브산으로부터 2,3-부탄디올로 전환되는 세 반응에 각각 관여하는 acetolactate synthase, acetolactate decarboxylase, 2,3-butanediol dehydrogenase로 추정되는 효소들을 암호화 하는 유전자들을 검증하였다. 이들 유전자들을 혐기성 조건의 대장균 에서 발현시킨 결과 $0.1 \mathrm{~g} / \mathrm{L} / \mathrm{OD}_{600}$ 의 2,3-부탄디올이 생성되었 고, 이로써 상기 유전자들이 2,3-부탄디올 생합성에 관여하는 효 소를 암호화하는 것으로 보고하였다(Kopke 등, 2014). 또 다른 연구에서는, C. ljungdahlii의 alcohol dehydrogenase를 암호화하 는 여러 유전자들 중, CLJU_c23220를 2,3-부탄디올을 생성하지 않는 C. acetobutylicum에서 발현시켜 그 기능을 검증한 것으로 보고하고 있다(Tan 등, 2015). 그 결과, 재조합된 C. acetobutylicum으로부터 $3.1 \mathrm{~g} / \mathrm{L}$ 의 2,3-부탄디올이 생성된 것을 확인 함으로써, 이 효소가 C. ljungdahlii의 아세토인으로부터 2,3-부 탄디올로의 전환반응을 촉매하는 것으로 보고하고 있다(Tan 등, 2015). 아직까지는 아세토젠에서 2,3-부탄디올을 생성하기 위한 대사공학적 균주개량 연구 결과가 없으나 2,3-부탄디올 생합성 에 관련된 효소들과 반응에 대한 연구들이 본격적으로 진행됨 에 따라, 앞으로 개발이 활발히 진행될 것으로 보인다.

\section{전 망}

합성가스를 이용하여 바이오 알코올을 생산한다는 것은 바이오 매스 이용 효율 측면에서 매우 유리한 점이 많다. 이론적으로 거의 모든 바이오매스를 $100 \%$ 에 가깝게 이용할 수 있다는 것 이 그 중 가장 큰 장점으로 꼽힌다. 이러한 장점이 현실화 되 기 위해서는 합성가스를 효율적으로 이용할 수 있는 바이오 알 코올 전환 미생물 개발이 매우 시급하다 할 수 있다. 합성가스 의 주성분과 부산물인 일산화탄소, 이산화탄소, 수소를 가장 효 율적으로 이용하여 바이오 알코올을 생합성할 수 있는 대사회 로는 우드-륭달 대사회로가 최적일 것으로 판단한다. 이들을 잘 활용하기 위해서는 이들 대사회로를 가지고 있는 아세토젠에 대 한 연구가 더욱 활발히 진행되어야 할 것으로 생각한다. 2010 년 이후 일부 아세토젠의 게놈서열이 계속 밝혀지고 있으며, 이 들 정보를 이용하여 게놈 수준의 네트워크 모델들이 개발되었 거나 개발되고 있다. 또한, 대사공학을 위한 게놈 편집 기술들 이 개발되고 있어 추후 게놈수준에서 재조합된 균주들이 조만 간 보고될 것으로 전망한다. 한편, 이와 같은 우드-륭달 대사회
로를 기존에 개발된 바이오 알코올 생합성 균주에 도입하여 합 성가스로부터 고효율로 바이오 알코올을 생산할 수 있는 균주 개발 전략의 개발도 필요할 것으로 전망한다.

\section{초 록}

최근 미생물을 이용하여 목질계 바이오매스로부터 에탄올, 부탄 올, 2,3-부탄디올과 같은 바이오 알코올을 생산하고자 하는 관 심이 매우 높아져 있다. 하지만, 목질계 바이오매스의 전처리 과정에서 높은 비용이 발생함과 동시에 리그닌과 같은 이용하 지 못하는 성분들이 상당부분을 차지하는 문제점들이 노출되고 있다. 이와 같은 문제 해결을 위하여 바이오매스를 합성가스로 전환하고, 이들을 이용하여 바이오 알코올을 생산하는 전략이 새로운 대안으로 부상하고 있다. 따라서, 본 연구에서는 합성가 스를 이용하는 미생물인 아세토젠(acetogen)을 소개하고, 이들의 중심대사회로인 우드-륭달 대사회로(Wood-Ljungdahl pathway) 를 리뷰하였다. 또한, 최근 합성가스로부터 바이오 알코올을 생 산하기 위한 대사공학 연구 전략을 리뷰하고, 향후 연구 방향 을 전망하였다.

Keywords 부탄올 - 아세토젠 - 에탄올 - 우드-륭달 대사회로 합성가스

감사의 글 본 연구는 한국연구재단의 이공분야기초연구사업(과제번호: NRF2016R1D1A3B04933184) 지원으로 수행되었습니다.

\section{References}

Anbarasan P, Baer ZC, Sreekumar S, Gross E, Binder JB, Blanch HW, Clark DS, Toste FD (2012) Integration of chemical catalysis with extractive fermentation to produce fuels. Nature 491: 235-239

Becker J, Wittmann C (2012) Bio-based production of chemicals, materials and fuels-Corynebacterium glutamicum as versatile cell factory. Curr Opin Biotechnol 23: 631-640

Bengelsdorf FR, Poehlein A, Linder S, Erz C, Hummel T, Hoffmeister S, Daniel R, Durre P (2016) Industrial acetogenic biocatalysts: a comparative metabolic and genomic Analysis. Front Microbiol 7: 1036

Bruant G, Lévesque M-J, Peter C, Guiot SR, Masson L (2010) Genomic analysis of carbon monoxide utilization and butanol production by Clostridium carboxidivorans Strain P7 $7^{\mathrm{T}}$. PLOS ONE 5: e13033

Chen GQ, Patel MK (2012) Plastics derived from biological sources: present and future: a technical and environmental review. Chem Rev 112: 20822099

Cho DH, Lee YJ, Um Y, Sang BI, Kim YH (2009) Detoxification of model phenolic compounds in lignocellulosic hydrolysates with peroxidase for butanol production from Clostridium beijerinckii. Appl Microbiol Biotechnol 83: 1035-1043

Chu BC, Lee H (2007) Genetic improvement of Saccharomyces cerevisiae for xylose fermentation. Biotechnol Adv 25: 425-441

Clomburg JM, Crumbley AM, Gonzalez R (2017) Industrial biomanufacturing: The future of chemical production. Science 355: 3620

Durre P, Eikmanns BJ (2015) C1-carbon sources for chemical and fuel production by microbial gas fermentation. Curr Opin Biotechnol 35: 6372

Islam MA, Zengler K, Edwards EA, Mahadevan R, Stephanopoulos G (2015) Investigating Moorella thermoacetica metabolism with a genome-scale 
constraint-based metabolic model. Integr Biol (Camb) 7: 869-882

Jang YS, Kim B, Shin JH, Choi YJ, Choi S, Song CW, Lee J, Park HG, Lee SY (2012a) Bio-based production of C2-C6 platform chemicals. Biotechnol Bioeng 109: 2437-2459

Jang YS, Lee JY, Lee J, Park JH, Im JA, Eom MH, Lee J, Lee SH, Song H, Cho JH, Seung do Y, Lee SY (2012b) Enhanced butanol production obtained by reinforcing the direct butanol-forming route in Clostridium acetobutylicum. mBio 3: e00314-12

Jang YS, Park JM, Choi S, Choi YJ, Seung DY, Cho JH, Lee SY (2012c) Engineering of microorganisms for the production of biofuels and perspectives based on systems metabolic engineering approaches. Biotechnol Adv 30: 989-1000

Jones SW, Fast AG, Carlson ED, Wiedel CA, Au J, Antoniewicz MR, Papoutsakis ET, Tracy BP (2016) $\mathrm{CO}_{2}$ fixation by anaerobic nonphotosynthetic mixotrophy for improved carbon conversion. Nat Commun 7: 12800

Kim DU, Kim HJ, Jeong YS, Na HB, Cha Y-L, Koo B-C, Kim J, Yun HD, Lee J-K, Kim H (2015) Enhanced saccharification of reed and rice straws by the addition of â-1,3-1,4-glucanase with broad substrate specificity and calcium ion. Appl Biol Chem 58: 29-33

Kim E-A, Lee S-Y, Lee S-Y (2016a) Quality characteristics of steamed rice bread prepared with different contents of proteolytic enzyme. Appl Biol Chem 59: 95-102

Kim M-S, Woo M-H, Chang Y-H, Chung N, Kim J-S (2016b) Biochemical characterization of a noble xylanase from Paenibacillus sp. EC116. Appl Biol Chem 59: 313-320

Kopke M, Gerth ML, Maddock DJ, Mueller AP, Liew F, Simpson SD, Patrick WM (2014) Reconstruction of an acetogenic 2,3-butanediol pathway involving a novel NADPH-dependent primary-secondary alcohol dehydrogenase. Appl Environ Microbiol 80: 3394-3403

Kopke M, Held C, Hujer S, Liesegang H, Wiezer A, Wollherr A, Ehrenreich A, Liebl W, Gottschalk G, Durre P (2010) Clostridium ljungdahlii represents a microbial production platform based on syngas. Proc Natl Acad Sci U S A 107: 13087-13092

Kopke M, Mihalcea C, Liew F, Tizard JH, Ali MS, Conolly JJ, Al-Sinawi B, Simpson SD (2011) 2,3-Butanediol production by acetogenic bacteria, an alternative route to chemical synthesis, using industrial waste gas. Appl Environ Microbiol 77: 5467-5475

Lagoa-Costa B, Abubackar HN, Fernandez-Romasanta M, Kennes C, Veiga MC (2017) Integrated bioconversion of syngas into bioethanol and biopolymers. Bioresour Technol 239: 244-249

Lee C-K, Jang M-Y, Park HR, Choo G-C, Cho HS, Park S-B, Oh K-C, An JB, Kim B-G (2016) Cloning and characterization of xylanase in cellulolytic Bacillus sp. strain JMY1 isolated from forest soil. Appl Biol Chem 59: 415-423

Liew F, Henstra AM, Kpke M, Winzer K, Simpson SD, Minton NP (2017) Metabolic engineering of Clostridium autoethanogenum for selective alcohol production. Metab Eng 40: 104-114

Lynd LR, van Zyl WH, McBride JE, Laser M (2005) Consolidated bioprocessing of cellulosic biomass: an update. Curr Opin Biotechnol 16: 577-583

Martin ME, Richter H, Saha S, Angenent LT (2016) Traits of selected Clostridium strains for syngas fermentation to ethanol. Biotechnol Bioeng 113: 531-539

Phillips JR, Atiyeh HK, Tanner RS, Torres JR, Saxena J, Wilkins MR, Huhnke RL (2015) Butanol and hexanol production in Clostridium carboxidivorans syngas fermentation: Medium development and culture techniques. Bioresour Technol 190: 114-121

Ragauskas AJ, Williams CK, Davison BH, Britovsek G, Cairney J, Eckert CA, Frederick WJ, Hallett JP, Leak DJ, Liotta CL, Mielenz JR, Murphy R, Templer R, Tschaplinski T (2006) The path forward for biofuels and biomaterials. Science 311: 484-489

Sauer M, Porro D, Mattanovich D, Branduardi P (2008) Microbial production of organic acids: expanding the markets. Trends Biotechnol 26: 100-108

Straathof AJ (2014) Transformation of biomass into commodity chemicals using enzymes or cells. Chemical reviews 114: 1871-1908

Tan Y, Liu ZY, Liu Z, Li FL (2015) Characterization of an acetoin reductase/ 2,3-butanediol dehydrogenase from Clostridium ljungdahlii DSM 13528. Enzyme Microb Technol 79-80: 1-7

Tracy BP, Jones SW, Fast AG, Indurthi DC, Papoutsakis ET (2012) Clostridia: the importance of their exceptional substrate and metabolite diversity for biofuel and biorefinery applications. Curr Opin Biotechnol 23: 364-381

Woo JE, Kim M, Noh HJ, Hwang N, Kim J-H, Lee SY, Jang Y-S (2016) Metabolic engineering of the genus Clostridium for butanol production. Kor J Microbiol 52: 391-397

Zverlov VV, Berezina O, Velikodvorskaya GA, Schwarz WH (2006) Bacterial acetone and butanol production by industrial fermentation in the Soviet Union: use of hydrolyzed agricultural waste for biorefinery. Appl Microbiol Biotechnol 71: 587-597 